\title{
COMENSAL, SERVIDOR Y ANFITRIÓN DEL BANQUETE DEL REINO
}

\author{
Rasgos cristológicos en Lc 14,1-24
}

\section{Introducción}

La experiencia de compartir la mesa no responde solo a la necesidad fisiológica de la nutrición, sino que nace de la relacionalidad que caracteriza al ser humano. Es expresión de la vocación de encuentro, de alegría y de fiesta que anida en lo más profundo de la persona. Por ello no sorprende que la Escritura esté poblada de escenas en las que los coprotagonistas de la historia salvífica se sientan juntos a la mesa y celebran los acontecimientos fundamentales que les dan identidad. La imagen del banquete llega al apogeo de su capacidad de evocar plenitud cuando describe la salvación escatológica que Dios, el protagonista de la historia, ofrece a su pueblo (Is 25,6-8) ${ }^{1}$.

Verdadero hombre y profundamente humano, el Hijo de Dios ha compartido también la mesa de los hombres. Ha asumido su misma forma de encuentro y se ha identificado con su misma manera de expresar la alegría. El Testamento de los Doce Patriarcas ${ }^{2}$ expresa el asombro ante el hecho de que Dios, haciéndose hombre, haya compartido la mesa con la humanidad:

1 A. Marx, «Le Dieu qui invite au festin», en C. Grappe (ed.)., Le Repas de Dieu. Das Mahl Gottes), WUNT 169 (2004), pp. 46-47; J. BoLYKI, Jesu Tischgemeinschaften, en WUNT II 96 (1998), p. 193.

2 Aunque el debate acerca de la historia de su composición es encendido, parece fuera de duda que en su forma actual se trata de una obra cristiana que ha incorporado material judío. Cf. J. Collins, The Apocalyptic Imagination. An Introduction to Jewish Apocalyptic Literature. The Biblical Resource Series. Grand Rapids, MI - Cambridge, ${ }^{2} 1998$, pp. 133ss. 


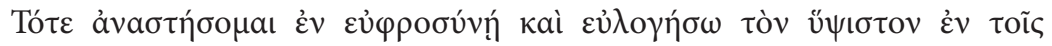

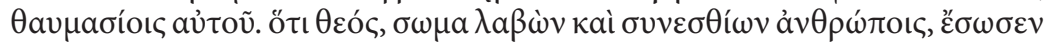
àv $\theta \rho \omega ́ \pi 0 v \varsigma^{3}$.

El autor menciona en este pasaje la esperanza futura de la resurrección. En ese contexto se esperaría razonablemente que hiciese referencia a la muerte y la resurrección de Jesús, fundamento de la fe en la resurrección futura. Sin embargo, su atención se dirige llamativamente a la comensalidad, medio de salvación y expresión concreta de la visita divina ${ }^{4}$.

Esta comensalidad de Jesús está atestiguada en los cuatro evangelios. Marcos lo presenta sentado a la mesa con publicanos y pecadores (Mc 2,15-17), escena que se convertirá en patrimonio sinóptico (Mt 9,10-13; Lc 5,29-32). El Jesús de Juan, en cambio, jamás se sienta a la mesa con ellos. Solo sus discípulos y sus amigos tienen este privilegio (Jn 2,1-12; 4,31-38; $12,2 ; 13,2 ; 21,4-14)$.

El scriba mansuetudinis Christi $^{5}$ explota este motivo de manera llamativa. Las escenas de banquetes atraviesan discreta y significativamente su evangelio, constituyendo aproximadamente el $20 \%$ de su obra ${ }^{6}$. Se ha llegado a afirmar que, en el tercer evangelio, «Jesus está siempre o yendo a una comida, en una comida o volviendo de una comida» ${ }^{7}$. El evangelista introduce además una novedad al hacer sentar a Jesús, con una audacia que quizá escandalizaría a Mateo, con los fariseos (Lc 7,36-50; 11,37-54; 14,1-24). En estos banquetes se confronta con ellos y hace presente la novedad del reino. Prostmeier sostiene que son un marco privilegiado para el discurso acerca de lo que separa a Jesús de los fariseos ${ }^{8}$. Las durísimas palabras que el Jesús mateano les dirige (Mt 23,1-36) aparecen en el tercer evangelio en el marco de una cena (Lc 11,37-54). Una palabra dura en un marco convival ${ }^{9}$.

3 Testamento de Simeón 6,7.

${ }^{4}$ Cf. O. Hofius, «Jesu Tischgemeinschaft mit den Sündern», en Neutestamentliche Studien, WUNT 132 (2000), p. 20.

5 Cf. Dante Alighieri, De Monarchia I, 18.

${ }^{6}$ Cf. P.-B. SmIT, Fellowship and Food in the Kingdom. Eschatological Meals and Scenes of Utopian Abundance in the New Testament. WUNT. Tübingen, 2008, p. 113.

7 Se trata de un logion anónimo, de paternidad incierta, citado en P.-B. SMIT, Fellowship and Food in the Kingdom, o. c., p. 114.

${ }^{8}$ Cf. F. Prostmeier, «Symposion-Begegnung-Rettung. Jesus als Bote des Heils», en L. Hauser / R. Prostmeier / C. Georg-Zöller (eds.), Heilsverkündigung und Heilserfahrung in frühchristilicher Zeit. SSB 60 (2008), p. 96.

9 Análogamente ubica el anuncio de la negación de los discípulos y de la traición de Pedro en el marco de la última cena. Cf. R. Brown, The Death of the Messiah. From Gethsemane to the Grave. A commentary on the Passion Narratives in the Four Gospels. The Anchor Yale Bible Reference Library I. London, 2008, p. 68 (hay ed. española). 
El evangelista se sirve con creces del motivo literario de la mesa compartida para presentar a Jesús. Si el Jesús joánico se revela de manera especial en las fiestas judías ${ }^{10}$, el lucano encuentra en los banquetes un espacio particular donde mostrar su rostro salvífico. Los banquetes lucanos son un locus de su manifestación cristológica y un espacio donde se hace presente la visita de Dios a su pueblo ${ }^{11}$. El banquete connota esta visita con los elementos propios de intimidad y de alegría. Podríamos casi afirmar

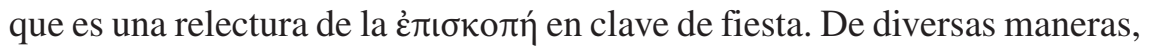
los comensales están implícitamente llamados a reconocer la presencia divina y a acoger el don de la salvación.

Este recurso lucano ha llamado la atención de los exegetas ${ }^{12}$. Ha sido estudiado especialmente a nivel literario, y las preguntas de esta aproximación versan sobre el origen de la imagen o su semejanza y diferencia con el género symposion de la literatura griega ${ }^{13}$. Abordamos este

10 Cf. R. INFANTE, Le feste di Israele nel vangelo secondo Giovanni. Milano, 2010, pp. 7-15.

${ }^{11}$ Cf. W. Grundmann, Das Evangelium nach Lukas. ThHK NT III. Berlin, ${ }^{91981, p .}$ 17; G. Hotze, «Jesus als Gast. Studien zu einem christologischen Leitmotiv im Lukasevangelium», en FZB 111 (2007), p. 13. Cf. F. G. UNTERGASSMAIR, «"Gott hat sein Volk heimgesucht“" (Lk 7,16b). Ein Spezifikum lukanischer Christologie», en M. SPIEKER / F. FISCHER (eds.), Glauben-Bezeugen-Handeln in Kirche, Gesellschaft und Schule. Paderborn, 1985, p. 64.

12 Cf. F. Bovon, Luc le théologien. Genève, ${ }^{3} 2006$, p. 514; P.-B. SмIт, Fellowship and Food in the Kingdom, o. c., p. 113. Entre otras obras podemos mencionar: W. BösEN, Das Mahlmotiv bei Lukas. Studien zum lukanischen Mahlverständnis unter besonderer Berücksichtigung von Lk 22. Saarbrücken, 1976, pp. 14-20; ID., Jesusmahl, Eucharistisches Mahl, Endzeitmahl. Ein Beitrag zur Theologie des Lukas, en SBS 97 (1980); D. Sмітн, From Symposium to Eucharist. The Banquet in the Early Christian World. Minneapolis, 2003; D. Moessner, Lord of the Banquet. The Literary and Theological Significance of the Lukan Travel Narrative. Minneapolis, 1989; M. BARTH, Das Mahl des Herrn. Gemeinschaft mit Israel, mit Christus und unter den Gästen. Neukirchen-Vluyn, 1987; H. Just JR., The Ongoing Feast. Table Fellowship and Eschatology at Emmaus. Collegeville, 1993; J. P. HEIL, The Meal Scenes in Luke-Acts. An Audience-Oriented Approach, en SBL Mon 52 (1999).

${ }^{13}$ El trabajo más influyente ha sido el de X. DE MEEÛs, «Composition de Lc XIV et genre symposiaque», en EThL 37 (1961), pp. 847-870. Su tesis fundamental es que Lucas se ha inspirado en el género symposion de la literatura griega para componer la escena de 14,1-24. Otros estudios seguirán su huella: J. DeLOBEL, «L'onction par la pécheresse», en EThL 42 (1966), pp. 415-475, y E. SPRINGS StEELE, «Luke 11:3754 - A Modified Hellenistic Symposium?», en JBL 103/3 (1984), pp. 379-394. En este trabajo nos distanciamos de la atribución estricta de estas perícopas al género griego. Aun dentro de la versatilidad del género, las diferencias con las escenas lucanas son inmensas. Remitimos a la crítica de W. Braun, Feasting and Social Rhetoric in Luke 14, en MS.SNTS 85 (1995), pp. 138-139. cf. G. HotzE, Jesus als Gast, o. c., 
trabajo con la intención de verificar en qué medida este motivo literario está al servicio de una intención más amplia: su comunión con la cristología lucana. Limitarse a una crítica del género hace correr el riesgo de reducir la riqueza del motivo del banquete y nos quedamos en la orilla de la interpretación del motivo ${ }^{14}$.

Con algunas excepciones ${ }^{15}$, llama la atención que obras consagradas a la teología lucana no dediquen ningún comentario al motivo del ban-

p. 236; C. Blomberg, «Jesus, Sinners, and Table Fellowship» en BBR 19.1 (2009), pp. 59-60. A lo allí dicho podemos agregar que la atribución al género symposion, en el mejor de los casos, podría reducirse solo a tres perícopas (Lc 7,36-50; 11,37-53; 14,1-24). Ello las alejaría formalmente del resto de las escenas de comidas que pululan en la trama narrativa. Si bien nada impediría que algunas de ellas fuesen presentadas con un género particular, nos parece más razonable interpretarlas en continuidad formal con las demás escenas. Por otra parte, es sabido que, durante el período helenístico, los symposia se convirtieron no rara vez en espectáculos de glotonería, embriaguez y desenfreno moral. Cf. W. Burket, «Oriental Symposia: Contrasts and Parallels», en W. J. SLAter (ed.), Dining in a Classical Context. Ann Arbor, 1991, p. 7. Cabría preguntarse si la sensibilidad exquisita de Lucas no hubiese encontrado al menos algunos reparos en servirse del symposion de manera tan comprometida. Es llamativo, por ejemplo, que, en el relato de la multiplicación de

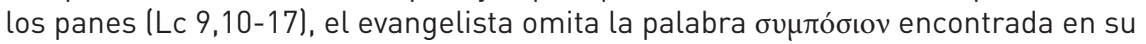
fuente (Mc 6,30-44).

14 X. de Meeûs no abre de manera explícita ningún espacio significativo para rastrear implicaciones cristológicas del uso del género. Incluso podría decirse que condiciona la cristología haciendo de Jesús el huésped principal que pronuncia un «discurso» sobre la humildad. «The common and distinguishing characteristic of the chief guest in these symposia is his wisdom», en E. SPRIngs StEELE, «A Modified Hellenistic Symposium?», a. c., p. 381. Según Springs Steele, consecuencia lógica de la asunción del symposion helénico es la imagen de Jesús como sabio. En Lc 7,36-50, a través del «diálogo socrático» sale a la luz este rasgo. «Further, it presents Jesus in the same fashion as Plato presents Socrates», p. 383.0 incluso más radical aún: se presenta a Jesús como «a Jewish Socrates», p. 392. Esta propuesta, a nuestro juicio, no logra sacar a la luz la originalidad de esta sabiduría ni ubicarla en un contexto más amplio. Si el conmovedor relato de Jesús con la mujer pecadora (Lc 11,37-50) se explicase meramente como una demostración de su sabiduría, entonces la presencia de la salvación y del perdón desbordantes de Dios necesariamente pasarían a un segundo plano y la cristología se vería saqueada en su riqueza. La sabiduría de Jesús y su condición de maestro constituyen un aspecto importante de la cristología lucana (LC 2,52; 11,31), pero, ¿se podría decir que esta es «la» característica del Jesús lucano en los banquetes?

15 Por ejemplo: W. Grundmann, Das Evangelium nach Lukas, o. c.; F. G. UnterGASSMAIR, "“Gott hat sein Volk heimgesucht" (Lk 7, 16b)», a. c.; A. DenAux, «The Theme of Divine Visits and Human (In)hospitality in Luke-Acts. Its Old Testament and Graeco-Roman Antecedents», en J. VerHEYDEN (ed.), The Unity of Luke-Acts. BETL 142. Leuven, 1999, pp. 255-279. 
quete desde una perspectiva cristológica ${ }^{16}$. G. Hotze se lamenta con razón y señala que se pasa por alto el potencial metafórico o la calidad teológica del motivo ${ }^{17}$.

A su juicio, la imagen de Jesús como huésped constituye un leitmotiv cristológico. Nuestro aporte sigue este surco y consideramos que, con este motivo, Lucas enriquece su poliédrico arte de relatar a Jesucristo. Ofrecemos el análisis de un texto medular para la comprensión de la relación entre cristología e imaginería convival: el tercer y último banquete en casa de un jefe fariseo (Lc 14,1-24). Su lugar destacado en el Reisebericht y la riqueza de temas que se da cita en sus veinticuatro versículos nos han movido a esta opción. Nos servimos de la Redaktionskritik para poner de relieve la teología que deja traslucir la pluma lucana. La comparación con otros textos bíblicos y extrabíblicos nos permite en varias ocasiones poner de manifiesto la hondura de un pensamiento que quiere estar al servicio de

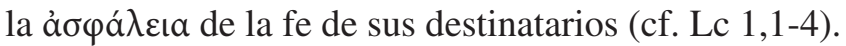

\section{Invitados al banquete escatológico (Lc 14,1-24)}

\subsection{Ubicación y contexto de la perícopa}

La sección central del evangelio está marcada por el Reisebericht (Lc 9,51; 10,38; 13,22.31-33; 14,25; 17,11-12; 18,31.35-36; 19,1.11.2829.37.41) ${ }^{18}$. Si con Grundmann dividimos esta sección en tres partes (Lc $9,51-13,21 ; 13,22-17,10 ; 17,11-19,27)^{19}$, nuestra perícopa se encuentra en

16 Algunos ejemplos: D. L. Bock, Proclamation from Prophecy and Pattern. Lucan Old Testament Christology, en JSNT.SS 12 (1987); P. PokoRny, Theologie der lukanischen Schriften. en FRLANT 174 (1997); M. A. PowELL, What are they saying about Luke? New York - Mahwah, 1989; G. SchneIDER, Jesusüberlieferung und Christologie. Neutestamentliche Aufsätze 1970-1990. Leiden, 1992; G. ScHNEIDER, Lukas, Theologe der Heilsgeschichte. Aufsätze zum lukanischen Doppelwerk, en BBB 59 (Königstein/ Ts.-Bonn); R. F. O 'Toole, Luke's Presentation of Jesus: A Christology, en Subsidia Biblica 25 (2004); A. VöGtLE, Gott und seine Gäste. Das Schicksal des Gleichnisses Jesu vom großen Gastmahl (Lk 14,16b-24; Mt 22,2-14), en BThSt 29 (1996).

17 G. Hotze, Jesus als Gast, o. c., p. 14.

18 Para una primera aproximación, cf. D. MoEssner, Lord of the Banquet, o. c., pp. 1-44. Este camino hacia Jerusalén reviste tanta importancia en el evangelio lucano que, análogamente a la clasificación de los salmos que cantan la alegría de peregrinar hacia la capital judía (Sal 120-134), podríamos considerar esta obra como «el evangelio de la subida».

19 W. Grundmann, Das Evangelium nach Lukas, o. c., p. 200. Para otras divisiones propuestas, cf. G. Hotze, Jesus als Gast, o. c., pp. 76 y .218. 
la segunda. Su inicio está marcado por una pregunta sobre la salvación, por la temática de la puerta estrecha y por los nuevos comensales de la mesa del reino (Lc 13,22-30).

Con ello, el clima narrativo es ya propicio para nuestra escena. En este marco tienen lugar diversos acontecimientos: la curación de un hidrópico y la controversia por el sábado (14,1-6), la exhortación a los invitados (14,7-11), la exhortación al anfitrión (14,12-14) y la parábola sobre el banquete $(14,14-24)$. Lucas ha reunido en este marco materiales de diversa proveniencia y a su pluma literaria se debe la unidad del relato final $^{20}$.

\subsection{En la mesa de un jefe fariseo durante el shabbat (Lc 14,1-6)}

Jesús se dirige a la casa de uno de los jefes fariseos ${ }^{21}$ para celebrar un banquete el día de sábado. Esa finalidad se describe con el semitismo

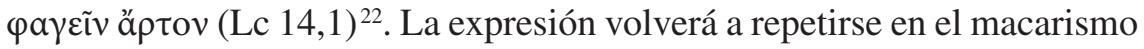
de Lc 14,15.

Una de las costumbres más difundidas consistía en invitar a algunas personas a participar de la comida, al término de la liturgia sinagogal ${ }^{23}$. El sábado debía celebrarse con una buena comida y bebida, además de vestimenta festiva ${ }^{24}$. Ese día, a diferencia de las dos habituales, había tres comidas. La principal de ellas era llamada ספעוּדָת $\operatorname{sexta}^{26}$.

20 Cf. G. Hotze, Jesus als Gast, pp. 221-225.

${ }^{21}$ Para una presentación de los fariseos, cf. J. T. CAROLL, «Luke's Portrayal of the Pharisees», en CBQ 50 (1988), pp. 604-621.

22 Cf. F. Bovon, L'Évangile selon Saint Luc Illb.. Commentaire du Nouveau Testament. Genève 1996, p. 417, n. 13. La formulación hebrea אבָל-לחילם significa simplemente «comer».

${ }^{23}$ Cf. J. Fitzmyer, El Evangelio según San Lucas III. Madrid, 1987, p. 589; F. Bovon, L'Évangile selon Saint Luc IIIb, o. c., p. 416, n. 13.

${ }^{24}$ Cf. H. Strack / P. Billerbeck, Kommentar zum Neuen Testament aus Talmud und

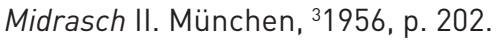

${ }^{25}$ Cf. Ibid.

26 Flavio Josefo, Autobiografía 54, n. 279. Es de notar que Flavio Josefo usa aquí

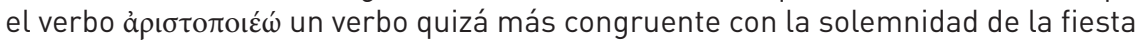
que el simple é $\sigma \theta i ́ \omega$ usado por Lucas. 
El sábado es el marco temporal de repetidas manifestaciones del ministerio salvífico de Jesús ${ }^{27}$. Ahora, por primera vez, esta salvación se manifiesta en el banquete postsinagogal, en el corazón de la semana judía. Jesús interroga a los fariseos sobre la legitimidad de curar en sábado. Ante su silencio $(14,4 a)$, obra de manera resuelta $(14,4 b)$. Para el Jesús lucano, la salvación no admite dilación. Las curaciones, junto con la expulsión de demonios, requieren una realización urgente, antes del tercer día (cf. Lc 13,32) ${ }^{28}$.

\subsection{Un relato congruente}

Sin embargo, no se trata de una curación más en sábado. Lucas prosigue el relato con la narración de la curación de un hidrópico. Se trata de un hapax diegumenon ${ }^{29}$. Dada su originalidad, se impone la pregunta: ¿cuál es la razón de la inserción del relato en este contexto? ¿Es posible encontrar alguna lógica con la trama del capítulo? Intentamos balbucear una respuesta.

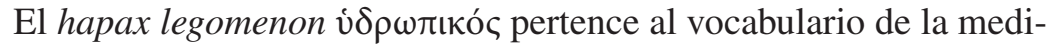
cina antigua y está documentado en los escritos de médicos de la época clásica ${ }^{30}$. Se trata de una afección temida. Para los antiguos, se manifestaba por inflamaciones, especialmente del vientre. Si se transformaba en una enfermedad crónica, podía provocar una muerte brusca. Entre sus causas, los científicos griegos individuaban los diversos excesos, en especial aquellos vinculados a la bebida ${ }^{31}$.

A nivel religioso se recomendaba para su tratamiento una estadía en el templo de Asclepio, en Epidauro ${ }^{32}$. Allí, una madre había recibido la revelación del tratamiento y de la curación de su hija hidrópica ${ }^{33}$.

27 Para una descripción sintética, cf. F. Bovon, L'Évangile selon Saint Luc IIIb, o. c., pp. 413-416.

${ }^{28}$ R. ScHWINDT vincula la afirmación del Jesús lucano de 13,31-33 con su contexto inmediato y menciona explícitamente 14,1-6 en relación con 13,32: «Zu Christologie und Zeitverständnis in Lk 13,31-33», p. 56.

29 Introducimos este concepto para designar una historia narrada por única vez.

30 Cf. Hipócrates, Aforismos VI, 8. 27. 35; Epidemias VII, 19-21; Plutarco, De vitando aere alieno 8; Filóstrato, Vida de Apolonio I, 6; III, 44.

31 Cf. F. Bovon, L'Évangile selon Saint Luc IIIb, o. c., p. 418.

32 Cf. R. Herzog, Die Wunderheilungen von Epidauros. Ein Beitrag zur Geschichte der Medizin und der Religion, en Philologus Supplementband 22,3 (1931), pp. 16-17.

33 Cf. ibid., pp. 28-29. 
En el judaísmo tenía también connotaciones religiosas ${ }^{34}$. En la Torá es el castigo por el adulterio de la mujer (Nm 5,21-22) y el salmista la augura para su enemigo (Sal 109,18). En la literatura rabínica, el hombre se presenta como compuesto de agua y sangre ${ }^{35}$. Solo la vida justa mantiene el equilibrio. El pecado hace que prevalezca o la sangre o el agua. En el primer caso, el hombre padecerá de lepra, en el segundo, de hidropesía. Entre los tipos de pecados que pueden provocarla se cuentan la lujuria, la difamación, la hechicería o la glotonería. Con este último nos encontramos con una semejanza con la cosmovisión griega: la hidropesía es consecuencia del exceso, especialmente de la bebida.

No podríamos descartar que este trasfondo haya estado en la base de la elección del marco para este hapax diegumenon. Lucas lo inserta en el marco del banquete por esta asociación entre la fiesta y una enfermedad que, según se creía, podía tener su origen en los excesos. De esta manera colorea soteriológicamente, desde el inicio, la escena convival, no con una curación cualquiera, sino con un relato congruente.

\subsection{La parábola a los comensales (Lc 14,7-11)}

La escena plantea el problema de los primeros lugares ${ }^{36}$. Los sinópticos mencionan el gusto desmedido de los escribas por los primeros puestos en las sinagogas y la búsqueda de los primeros lugares en los banquetes. Aquí, Lucas pone de relieve una de las perlas de su teología: la exaltación de los humildes ${ }^{37}$. Tenuemente, la escena se colorea de tinte escatológico.

${ }^{34}$ Cf. F. Bovon, L'Évangile selon Saint Luc IIIb, o. c., p. 418.

35 Cf. Levítico Rabbá 15: WaR 15,2 (115), citado en H. Strack / P. Billerbeck, Kommentar zum Neuen Testament aus Talmud und Midrasch II, o. c., p. 203.

36 La cuestión de los lugares es un tema presente en los symposia greco-romanos. Cf. Platón, El Banquete 177; Plutarco, Septem sapientium convivium 148-149; D. E. Sмітн, «Table Fellowship», a. c., pp. 617-618. Sin embargo, a nuestro juicio, las diferencias son de relieve. Por otra parte, el tema, no desconocido en la sabiduría veterotestamentaria (Prov 25,6-7; Sir 1,30; 3,17-18) y la tradición rabínica, nos sorprende con una enseñanza muy cercana a la lucana. Cf. LvR 1 (105), en H. StRACK / P. BillerbeCK, Kommentar zum Neuen Testament aus Talmud und Midrasch II, o. c., p. 204. Ya R. Bultmann, Die Geschichte der synoptischen Tradition. Göttingen, ${ }^{2} 1931$, p. 108, vinculaba la escena a la tradición sapiencial judía. Es claro que la noticia sobre el amor desordenado a los primeros puestos proviene de la fuente marcana (Mc 12,38-40; cf. Mt 23,6-7; Lc 20,45-46). Estos son los únicos casos en toda la Escritu-

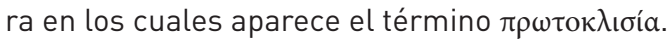

37 Cf. H. Douglas Buckwalter, The Character and Purpose of Luke's Christology (1996), citado en F. Bovon, Luc le Théologien, o. c., p. 490. No una mera lección sobre 
El logion habla de una invitación eis yápoov y de la necesidad de escoger el último lugar (Lc 14,8-11). El término yá más, en la exhortación a la vigilancia en la parábola de los siervos que esperan el regreso de su señor (Lc 12,36).

El sentido del logion no se agota en un plano parenético-sociológico que, partiendo del caso concreto de las mesas, se proyecte al conjunto de toda la existencia ${ }^{38}$. La mención de la humillación de los soberbios y la exaltación de los humildes (Lc 14,11) sitúa el apotegma en un nivel teológico-escatológico ${ }^{39}$. Las formas futuras de la expresión y el passivum divinum parecen un indicio de esta connotación ${ }^{40}$. El lector ya se ha encontrado desde las primeras páginas de la obra dirigida a Teófilo con la constatación de que Dios dirige su mirada a los humillados y cambia la suerte de los hombres (Lc 1,48-52). Esta convicción atraviesa la obra lucana (Lc 6,21-25; 10,15; 14,11; 18,14; Hch 2,22-36; 3,13-21). Sus parábolas, al igual que la teología de la cruz paulina, respiran esta convicción (Lc 10,2937 ; 15,11-32; 16,19-31; 18,9-14; cf. 1 Cor 1,26-31; 2 Cor 8,9; Flp 2,6-11) ${ }^{41}$. $\mathrm{El}$ autor ha bebido del Antiguo Testamento ${ }^{42}$. No sorprende que el mundo rabínico conozca paralelos semejantes ${ }^{43}$.

Grundmann sostiene que Lucas, al ampliar la cita de Is 40,3 de su

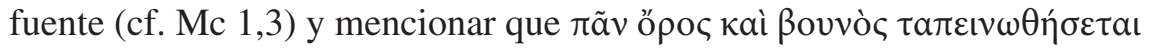

humildad como se propone en X. DE MeEÛs, Composition de Lc XIV, o. c., pp. 863-864. La intepretación de De Meeûs, además de empobrecer, en cierto sentido, la cristología lucana, deja más que en la penumbra la dimensión histórico-salvífica y escatológica con la que está teñido el banquete lucano.

38 Cf. F. Bovon, L'Évangile selon Saint Luc IIIb, o. c., p. 433; G. Hotze, Jesus als Gast, o. c., p. 245. Tampoco se agota, a nuestro juicio, en un nivel solo «espiritual», como propone J. KILGALLEN, Twenty Parables of Jesus in the Gospel of Luke, en: Subsidia Biblica 32 (2008), pp. 75-79. El exegeta norteamericano no menciona en absoluto la dimensión escatológica.

39 Cf. F. Bovon, L'Évangile selon Saint Luc IIIb, o. c., p. 428.

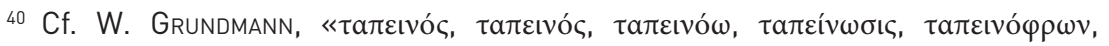

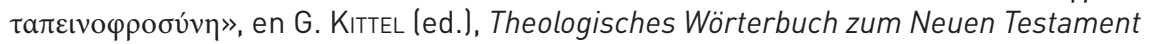
VIII. Stuttgart, 1969, p. 16. Ya J. JeremiAs, Die Gleichnisse Jesu. Göttingen, 51962, pp. 191-192, afirmaba esta connotación a diferencia de un paralelo hillelita.

41 Cf. E. HAMEL, «Le Magnificat et le renversement des situations», en Gr 60 (1979), pp. 65-70.

42 Para algunos paralelos fuera del mundo bíblico, cf. W. ECKEY, Das Lukasevangelium. Unter Berücksichtigung seiner Parallelen II. Neukirchen-Vluyn, ${ }^{2} 2006$, p. 650; F. Bovon, L'Évangile selon Saint Luc IIla, o. c., p. 91, n. 73.

43 Cf. H. Strack / P. Billerbeck, Kommentar zum Neuen Testament aus Talmud und Midrasch I, o. c., pp. 774; 921. 
(Lc 3,5), interpreta la enseñanza isaiana como expresión del obrar escatológico de Dios ${ }^{44}$ : el humillar a los poderosos y el exaltar a los humildes le son acciones inherentes. Será también lo que ocurrirá en la historia del comensal galileo ${ }^{45}$. Pero su humillación no será solo la cruz, sino también su elección del último lugar. Lucas presenta a Jesús con la imagen del siervo de la mesa. El Jesús lucano, al hablar de los «puestos» entre sus discípulos, en lugar de la imagen del $\lambda u ́ \tau \rho o v$ ảvtì $\pi \mathrm{o} \lambda \lambda \tilde{\omega} v$, propia de su fuente (Mc

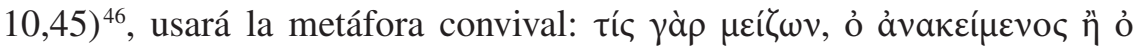

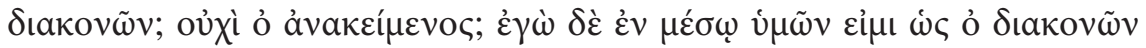
(Lc 22,27). Este exemplum inédito sirve a los discípulos para asumir una actitud análoga.

Lucas ha insertado el logion sobre la humillación-exaltación en el marco convival y la ha vinculado así al tema del banquete del reino. Esta dimensión escatológica cristalizará explícitamente en la palabra dirigida al anfitrión sobre la resurrección de los justos $(\mathrm{Lc} 14,14)$ y en la parábola final del banquete del señor (Lc 14,15-24).

\subsection{Una comensalidad no convencional (Lc 14,12-14)}

La nueva sección se abre con una palabra de Jesús al anfitrión. Nos encontramos con el texto que quizá refleja el mayor trabajo redaccional ${ }^{47}$. Jesús exhorta al fariseo a no invitar a su banquete a aquellos que pueden devolver la invitación (Lc 14,12). Ello no solo no tiene nada de mérito (cf. Lc 6,32-35), sino que además acarrea consecuencias escatológicas: la

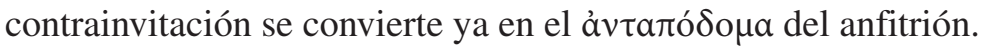

El segundo miembro de la exhortación se formula de manera positi-

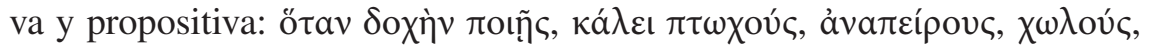
$\tau v \varphi \lambda$ ov́c (Lc 14,13). No se trata de dar limosna o de socorrer a los desfavorecidos, sino que se requiere mucho más: hacerlos partícipes de la doch, festiva de su propia casa. Aquí no hay posibilidad de recibir retribución

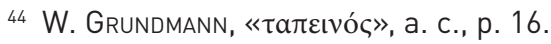

45 Cf. W. Eckey, Das Lukasevangelium, o. c., p. 653; H. Douglas Buckwalter, The Character and Purpose of Luke's Christology, o. c., p. 289.

46 La ausencia de este logion ha desempeñado un rol importante en la tesis que sostiene que, según el tercer evangelista, la muerte de Jesús no tendría un valor salvífico. La conveniencia de una imagen de servidor de las mesas, en un contexto de cena, motivo literario relevante de su teología, podría explicar en alguna medida esta omisión.

47 Cf. G. Hotze, Jesus als Gast, o. c., p. 227. 
alguna. Los absolutamente desprovistos no tienen con qué devolver. Esta imposibilidad de retribución abre a la intervención de Otro que devuelve

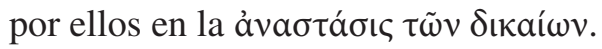

Esta expresión es única en el Nuevo Testamento e incluso en el ju-

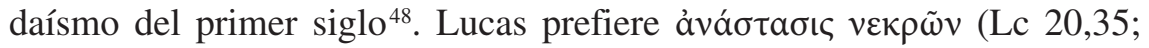
Hch 4,$2 ; 17,32 ; 23,6 ; 24,21 ; 26,23)$. La creencia en la resurrección era un artículo de fe aceptado por los fariseos y los distinguía de los saduceos (cf. Lc 20,27; Hch 23,8) ${ }^{49}$.

La caridad para con los pobres está presente en la piedad veterotestamentaria ${ }^{50}$ y en la literatura judía ${ }^{51}$. El Jesús de Lucas no es un innovador absoluto. Sin embargo es quizá el que se vincula de manera más explícita con ellos y el que relaciona su misión salvífica de manera solemne con los outcasts de la historia. Citando las palabras del profeta Isaías (61,1-2; $58,6)$, se identifica con el Ungido que hace presente la salvación, que tiene

48 Cf. C. Cavallin, «Bienheureux seras-tu... à la résurrection des justes. Le macarisme de Lc 14,14», en À cause de l'Évangile. Études sur les Synoptiques et les Actes; offertes au P. Jacques Dupont, O.S.B., à l'occasion de son 70e anniversaire, en LD 123 (1985), pp. 531-546.

49 Cf. Flavio Josefo, Guerra judía II, 163; Antigüedades judías XVIII, 14. Para un tratamiento sobre el origen de la fe en la resurrección en Israel, remitimos a C. A. BLANCO, «Hipótesis principales sobre el origen de la idea de resurrección de los muertos en el judaísmo», en Estudios Bíblicos LXVIII (2010), pp. 429-472.

50 YHWH prescribe la donación del diezmo del año, cada trienio, a cuatro categorías de personas: al levita, al forastero, al huérfano y a la viuda. Ellos podrán así «comer y saciarse» mientras que el benefactor recibirá la bendición divina. Los dones habrán de ser colocados a las puertas (Dt 14,28-29). Una exhortación a compartir la mesa aparece con ocasión de la fiesta de las Semanas (Dt 16,10-11) y de las Tiendas (Dt 16,13-14). El libro de Tobías hace mención de la invitación de un pobre a compartir la propia mesa, en el marco de Pentecostés (Tob [S] 2,1-2). Tobit relata la práctica de entregar el tercer diezmo a los desprotegidos y precisa que la Ley implica también una comida compartida. Menciona su deseo de compartir el

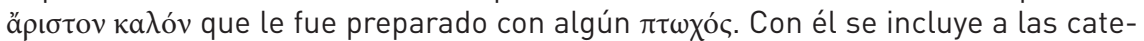
gorías de personas prescriptas en el Deuteronomio, con excepción del levita (Tob $[S] 1,8)$. El elenco lucano de cuatro categorías de personas no se encuentra en ningún pasaje veterotestamentario. El más cercano es el texto de la autoapología de Job, donde aparece una amplia lista de marginados sociales (Job 29,12-16), de los cuales la lista lucana comprende tres.

51 Cf. Abot RN 7 Anf., citado en H. Strack / P. Billerbeck, Kommentar zum Neuen Testament aus Talmud und Midrasch II, o. c., 206-207. El texto describe la hospitalidad de Job. La causa de sus sufrimientos se explica por una carencia de esa hospitalidad en comparación con la de Abrahán. El patriarca es superior a Job en cuanto que sale a buscar a sus huéspedes y les da pan de trigo, vino y carne. 
como destinatarios primeros a los pobres e indigentes (Lc 4,16-21) ${ }^{52}$. Esta opción por los marginados permitirá reconocerlo como el mesías escatológico (Lc 7,18-23).

Podemos decir que la comensalidad que Jesús propone a su anfitrión está en continuidad con uno de los trazos más importantes de la cristología lucana. La proclamación solemne en Nazaret ha marcado el inicio de su misión (Lc 4,16-22). Ahora, en el centro del Reisebericht, el Jesús lucano exhorta a acoger a los mismos que él ha acogido en su ministerio. Se trata de acoger y de hacer sentar en la propia mesa a los que él ha hecho «sentar» a la mesa de su salvación.

\subsection{La parábola del banquete (Lc 14,16-24)}

La parábola del banquete constituye el clímax de toda la escena. Es el punto teológico culminante ${ }^{53}$. Aquí se hace explícita la vinculación del banquete con el reino. Ya Lucas ha aludido a su realidad en términos convivales en el logion sobre la puerta estrecha (Lc 13,22-30). Nuestra parábola desarrolla y describe esta realidad y exhorta a sus interlocutores a optar por él. La última relación explícita la encontraremos en el marco de la última cena (Lc 22,16-18).

El tono escatológico ha ido subiendo progresivamente no solo dentro de Lc 14,1-24, sino además en la narración del viaje jerosolimitano (cf. Lc 12,35-48; 13,22-30), donde se tematiza, según E. Schweizer ${ }^{54}$, la cuestión soteriológica fundamental acerca de la entrada o no en el reino de Dios. Nuestra parábola marca un hito significativo en esta perspectiva. Mencionamos dos razones, entre otras seguramente posibles.

En primer lugar ofrece una profundización del diálogo entre Jesús y el personaje que ha hecho la pregunta por la salvación (Lc 13,23). La parábola del banquete alude al drama de los que quedan excluidos y menciona la participación de nuevos invitados (Lc 14,22-23). Ello está en continuidad con la afirmación de la novedosa comensalidad del reino (Lc 13,29).

Por otra parte, en este punto asistimos al encuentro entre el motivo de la comensalidad que lo ve a Jesús como invitado y la comensalidad que

52 G. Rossé, Il Vangelo di Luca. Commento esegetico e teologico. Roma, ${ }^{42006, p .}$ 155: «I poveri sono costantemente presenti: Lc 6,20-22; 7,22; 14,13.21; ancora 1,53; $6,24 \mathrm{ss} ; 8,14 ; 12,13-34 ; 14,15-24 ; 16,19-31$ ecc.».

53 Cf. G. Hotze, Jesus als Gast, o. c., p. 249.

54 E. Schwelzer, Das Evangelium nach Lukas. NTD 3. Göttigen, 1982, p. 108. 
Dios ofrece a los hombres. Esta última no se entiende sin la referencia al ministerio de Jesús y a sus destinatarios privilegiados. Nuestro pasaje engozna la cristología del comensal que se sienta a la mesa de los hombres y la imagen del servidor del banquete del reino. El anfitrión es el Padre, pero ya se insinúa tenuemente el rol de anfitrión que tiene Jesús al hablar de «mi cena» (cf. Lc 14,24). Su imagen de anfitrión ya ha aparecido en la trama lucana (cf. Lc 9,11-17) y cristalizará de manera especial en la última cena (cf. Lc 22,14-20). El Jesús de Lucas no se entiende si se prescinde de la interrelación entre el huésped, el servidor y el anfitrión del banquete del reino.

La parábola proviene de material tradicional. Lucas la encuadra con un macarismo (Lc 14,15) y con una sentencia final que constituye la conclusión de todo el episodio ( $\operatorname{Lc} 14,24)^{55}$. Contamos con tres versiones: en el primer evangelio (Mt 22,1-14) ${ }^{56}$ y en el Evangelio de Tomás (EvTom $64)^{57}$, además de la perícopa lucana.

\subsubsection{La introducción a la parábola}

Lucas introduce la parábola con el macarismo de uno de los comensales que ha escuchado la exhortación al anfitrión (cf. Lc 14,12-14). La dimensión escatológica que la afirmación sobre la resurrección de los justos había puesto de relieve es ahora acentuada: el comensal vincula explícitamente lo dicho por Jesús al banquete del reino (Lc 14,15). Llegamos a una suerte de endíadis, y casi podríamos hablar de una «resurrección para el banquete».

Por su construcción simple ${ }^{58}$, el macarismo puede haber sido creado tanto por Lucas como por la tradición anterior. La imagen de un banquete post mortem no era extraño al mundo mediterráneo ${ }^{59}$. Lucas la utiliza también en el contexto de la última cena de Jesús con sus discípulos (Lc 22,16.18.30). A nivel teológico, el macarismo desempeña un rol importan-

55 Cf. G. Hotze, Jesus als Gast, o. c., pp. 233-234; W. Braun, Feasting and Social Rhetoric in Luke 14, o. c., p. 132.

56 Cf. D. Marguerat, Le jugement dans l'Évangile de Matthieu. Genève, 1981, pp. 325-344; F. Bovon, L'Évangile selon Saint Luc, IIlb, o. c., p. 447.

57 Para esta última versión nos servimos del texto y de las traducciones ofrecidas en K. AlAND, Synopsis quattuor evangeliorum. Locis parallelis evangeliorum aprocryphorum et Patrum adhibitis edidit. Stuttgart, ${ }^{15} 2005$. Cf. F. HAHN, «Das Gleichnis von der Einladung zum Festmahl», en Studien zum Neuen Testament I, en WUNT 191 (2006), p. 338.

58 Cf. W. Braun, Feasting and Social Rhetoric in Luke 14, o. c., p. 63.

59 Cf. P.-B. SмIт, Fellowship and Food in the Kingdom, o. c., pp. 83-84. 


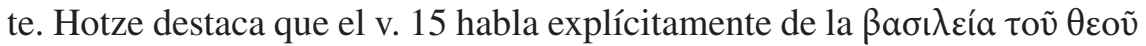
en relación directa con el motivo de la cena. De esta forma, a su juicio, queda claro que las imágenes de banquete, tanto en el contexto anterior de la parénesis como en el de la parábola, están en relación con el reinado escatológico de Dios, con sus criterios y con sus aspirantes ${ }^{60}$.

El pasaje se tiñe con la teología del banquete del reino. Se trata de un tema ya presente en la literatura judía y una de las imágenes más significativas para describir la comunión, la alegría y la salvación ${ }^{61}$. Lo pone de manifiesto Rossé: «En los ambientes apocalípticos, populares y rabínicos, el reino futuro de Dios puede ser visto como un espacio, una casa en la cual se festeja comiendo juntos» ${ }^{62}$.

\subsubsection{La invitación al banquete}

El Evangelio de Tomás comienza mencionando que un hombre (rōme) tenía huéspedes. Tras la preparación de la cena (dypnon), el hombre envía a su siervo con la finalidad de invitarlos.

El relato de Mateo se abre con la presentación de un äv $\theta \rho \omega \pi$ ๔ $\beta a \sigma ı \lambda \varepsilon v ́ c$ (Mt 22,2) que organiza una fiesta de bodas para su hijo. La alusión a Dios es evidente para un judío y para el oyente (cf. Mt 18,23) ${ }^{63}$. Con la mención del hijo, la parábola se colorea cristológicamente desde el principio. Los intermediarios de la invitación son «siervos» (Mt 22,3a), entendidos como los profetas y apóstoles. Nos encontramos con una interpretación de la historia de Israel (cf. Mt 21,34-39).

La versión lucana se acerca en algunos aspectos a la del evangelio

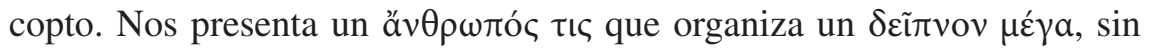
precisar ningún acontecimiento que lo origine. Se trata solo de una iniciativa generosa del anfitrión. Mientras que Mateo habla de un ápıбтóv (Mt $22,4)$, Lucas lo describe como la comida que tiene lugar durante la tarde, al igual que el dypnon del Evangelio de Tomás.

60 G. Hotze, Jesus als Gast, o. c., p. 251.

61 Cf. G. Rossé, Il Vangelo di Luca, o. c., p. 582; W. ECKEY, Das Lukasevangelium, o. C., p. 660; 0. Hoflus, «Jesu Tischgemeinschaft mit den Sündern», a. c., p. 32; T. SöDING, «Das Gleichnis von Festmahl (Lk 14,16-24 par. Mt 22, 1-10). Zur ekklesiologischen Dimension der Reich-Gottes-Verkündigung Jesu», en R. KampLIng / T. SöDING (eds.), Ekklesiologie des Neuen Testaments. Festschrift K. Kertelge. Freiburg, 1996, p. 66.

62 G. RossÉ, Il Vangelo di Luca, o. c., 582. Cf. 1 En 62,14; 2 Bar 29,4; bShab 153c; Av 4,16, citados en F. Bovon, L'Évangile selon Saint Luc IIIb, o. c., p. 449, n. 31.

${ }^{63}$ Cf. U. Luz, El Evangelio según san Mateo III. Salamanca, 2003, p. 316. 
Con respecto a la figura del siervo, a diferencia de la versión mateana, donde se utiliza el plural, y de la versión copta, donde su función no parece destacada, la elaboración lucana permite hipotetizar una alusión cristológica ${ }^{64}$. Hotze vincula la función intradiegética del siervo con el ministerio comensal de Jesús a lo largo de toda la trama: en el siervo de la parábola es posible ver al Jesus que entra y sale de las casas ${ }^{65}$. A su juicio, la vinculación con el trasfondo teológico de la visita divina parece clara, y ello tiene consecuencias para la cristología: «En la imagen de las diversas invitaciones a la comida a través del envío del siervo se percibe el envío de visita de Cristo. De esta forma, Lc 14 contiene una cristología oculta del envío» ${ }^{66}$. A favor de una alusión cristológica habla el rol importante del siervo en la trama del relato y la mención de los excluidos como nuevos invitados al banquete (Lc 14,21). La misión del siervo de traer a los outcasts guarda semejanzas con la misión de Jesús (Lc 4,16-21), y la imagen del siervo del banquete no es ajena a la descripción lucana (Lc 12,37; 22,27). Si esta interpretación es correcta, Jesús aparece aquí como el servidor del banquete del reino.

\subsubsection{La reacción del anfitrión}

En el evangelio copto, el siervo informa al anfitrión de que los invitados se han excusado, y este lo envía a los caminos a buscar y a traer a los que encuentre (EvTom 64,11b). La finalidad está centrada en los comensales: para que coman la cena (cf. EvTom 64,11c).

Mateo menciona una reacción violenta del rey (Mt 22,7). El texto parece reflejar la situación de Jerusalén del año $70^{67}$ e interpretar su destrucción como castigo por el rechazo a los profetas y a Jesús, interpretación no ausente en la literatura judía ${ }^{68}$. Sigue un nuevo envío de los siervos (Mt

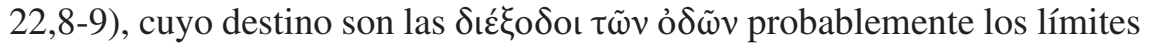

${ }^{64}$ Cf. G. Hotze, Jesus als Gast, o. c., p. 252; P.-B. Smit, Fellowship and Food in the Kingdom, o. c., p. 164. Se ha propuesto asimismo ver una alusión a Jesús en la figura del anfitrión. cf. A. VöGTLE, Gott und seine Gäste. Das Schicksal des Gleichnisses Jesu vom großen Gastmahl, en BThS 29 (1996), p. 35.

65 Cf. G. Hotze, Jesus als Gast, o. c., p. 257.

66 Ibid., p. 260.

${ }^{67}$ Cf. U. Luz, El Evangelio según san Mateo III, o. c., p. 319.

${ }^{6}$ Cf. Schab 119ss; QohR 3,16,1; ExR 31,16; cf. U. Luz, El Evangelio según san Mateo III, o. c., p. 320, n. 57. 
del territorio del monarca ${ }^{69}$. Este destino es cercano al que vierte el texto gnóstico (EvTom 64,11) y a la segunda orden del señor en el tercer evangelio (Lc 14,23). Los destinatarios permanecen indeterminados, pero es posible que se piense en la misión de los paganos (cf. Mt 21,43) ${ }^{70}$.

En la versión de Lucas, el siervo informa a su señor acerca de lo

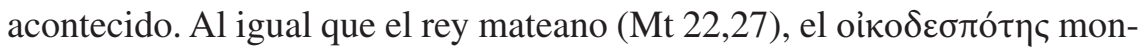
ta en cólera (Lc 14,21). Pero, a diferencia de la drástica decisión bélica del rey, el señor decide ampliar la lista de sus invitados y ordena a su siervo una nueva misión, desdoblada en dos momentos ${ }^{71}$. Aquí nos encontramos con una intervención redaccional que pone de relieve la intención del evangelista de los humildes.

\subsubsection{Los nuevos comensales}

El evangelista comienza refiriendo la nueva orden. El siervo ha de

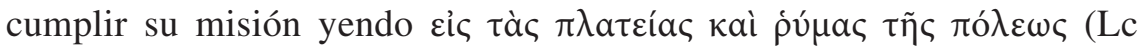
14,21). Este binomio no es frecuente en la Escritura: aparece apenas un par de veces, en situaciones contrapuestas. La primera de ellas es la lamentación por Moab, donde se describe la situación trágica de sus habitantes (Is 15,3). La segunda expresa la acción de gracias de Tobit y describe la reconstrucción de Jerusalén (Tob 13,17-18). En el evangelio de Lucas, las $\pi \lambda \alpha \tau \varepsilon \tilde{a}$ l han sido loci de la enseñanza de Jesús $(\operatorname{Lc} 13,26)$. Ahora las $\pi \lambda \alpha \tau \varepsilon i \alpha$ y las $\rho \tilde{u} \mu \alpha$ de la ciudad se convierten en testigos de una invitación inédita a la participación de un banquete hasta antes imposible.

La lista que el evangelista elenca reproduce aquella de los comensales propuestos al anfitrión (Lc 14,21). La lista se inserta -observa Bovonen la tradición veterotestamentaria de la misericordia de Dios y de la prioridad que él da a los pequeños, a los despojados, a los marginados y enfermos $^{72}$.

69 Mateo es el único hagiógrafo del Nuevo Testamento en emplear el término

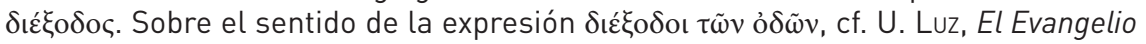
según san Mateo III, o. c., p. 321, n. 63.

70 Cf. ibid., p. 322.

71 Observa U. Luz, El Evangelio según san Mateo III, o. c., p. 312: «Mt y EvTom coinciden en que el esclavo, después de la negativa de los invitados, solo es enviado una vez a las calles. Parece que conservaron en eso el relato original».

72 Cf. F. Bovon, L'Évangile selon Saint Luc IIIb, o. c., p. 452. 
La opción por los pobres tras el rechazo de un invitado distinguido está testimoniado en la literatura rabínica ${ }^{73}$. Sin embargo, este texto no precisa que se trata de compartir la mesa, sino que podría entenderse como la decisión de que los pobres aprovechen la comida preparada, de manera análoga a la finalidad de la versión gnóstica (EvTom 64,11).

La nueva invitación del señor de la parábola lucana se encuentra en una relación íntima con el ministerio de Jesús y la cristología esbozada en la sinagoga de Nazaret (Lc 4,16-21). Por medio del ministerio de Jesús, Dios ha invitado a los marginados al banquete de su reino. Si bien la piedad para con el pobre está arraigada en el Antiguo Testamento, existen algunas prácticas que marginan a las categorías de personas que el señor lucano incluye en su invitación. El Levítico prescribe que los que padecen algún defecto físico queden excluidos del sacerdocio (Lv 21,17-21). Los defectos físicos no impiden comer del pan de la ofrenda, sin embargo no pueden entrar hasta el velo del Templo ni acercarse al altar (Lv 21,22-23). La legislación enumera doce defectos físicos que impiden el acceso al sacerdocio, de manera semejante a lo que ocurre en las cortes reales (cf. Dn 1,3ss) ${ }^{74}$. Un soberano podía ser ofendido por la presencia de una persona defectuosa. Un relieve particular parece tenerlo la ceguera y la renguera ${ }^{75}$.

Además de esta exclusión del sacerdocio, un texto de la Regla de la Congregación nos permite percibir la vigencia de preceptos análogos hasta una época tardía. En 1Q28a [1QSa] 2,2-10) ${ }^{76}$, un texto con un marcado tono escatológico ${ }^{77}$, se alude claramente a la práctica de la exclusión de determinadas personas. El documento acaba de presentar a los hombres de renombre (אנושי השם) que pueden participar en las convocatorias para las diversas

73 Cf. pSanh 6, 23 , citado en H. Strack / P. Billerbeck, Kommentar zum Neuen Testament aus Talmud und Midrasch II, o. c., p. 232. La datación de esta parábola es sumamente tardía, hacia el siglo Iv d. C., por lo que, a juicio de P.-B. Smit, la conexión con el mundo lucano es altamente improbable. Cf. P.-B. SMIT, Fellowship and Food in the Kingdom, o. c., p. 159, n. 348. De manera análoga opina T. SöDING, «Das Gleichnis von Festmahl», o. c., p. 70. No obstante, aun cuando la redacción de la parábola rabínica sea posterior, no es fácil datar sus orígenes en la tradición oral. Al menos podemos decir que una acción de este género no es extraña a la piedad veterotestamentaria.

74 Cf. E. Gerstenberger, Leviticus. A Commentary. OTL. Louisville, ky, 1996, pp. 316-318.

${ }^{75}$ Cf. ibid., p. 316. Cf. 2 Sam 5,8.

76 El texto original puede verse en D. BARThÉLEMy / J. T. MILIK, Discoveries in the Judaean Desert I. Oxford, 1955, p. 110. Otro texto importante que no podemos tratar es $1 \mathrm{QM} 7,4$.

77 Cf. F. García Martínez, Textos de Qumrán. Madrid, 1992, pp. 143, 177-178. 
deliberaciones comunes en Israel. Inmediatamente sigue la restricción: todo hombre afectado por alguna impureza (איש מנוגע באחת מכול טמאות האדם)

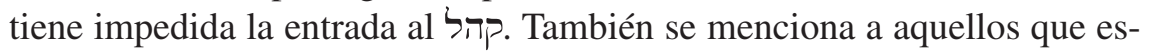
tán contaminados en su carne o que están paralizados en alguno de sus miembros (וכול מנוגע בבשרו נכאה רגלים או ידים). El texto nombra explí-

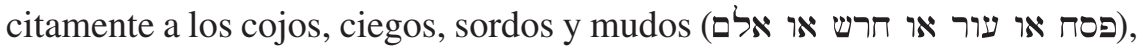

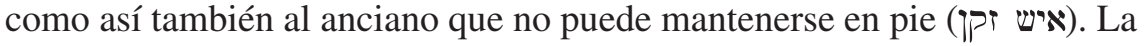
exclusión se debe a que la asamblea goza de la presencia angélica, y tales personas defectuosas podría constituir un agravio (כיא מלאכי קודש [בער]ם). Su participación en la asamblea solo es posible por medio de una persona sana, que podrá transmitir a la asamblea su palabra en caso de ser opor-

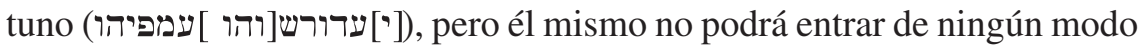

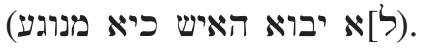

El texto prosigue con la descripción del orden de la asamblea con ocasión de la entrada del Mesías de Israel ${ }^{78}$ y alude a la participación en el banquete común. Contiene imaginería del motivo del banquete mesiánico ${ }^{79}$ (1Q28a [1QSa] 2,11-22). El texto ofrece indicaciones para el momento en el cual Dios

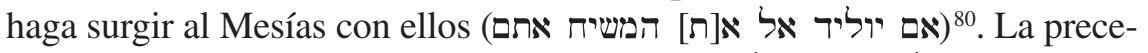

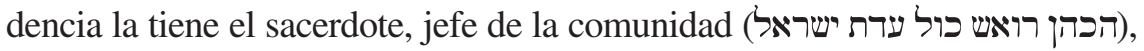

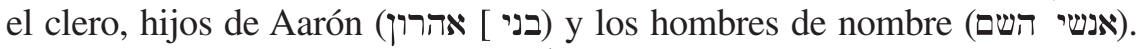
Tras la entrada del Mesías de Israel (משני[יח ישראל), los jefes de los clanes de Israel se sentarán ante él (לפניו). Los jefes de los clanes de la congregación, con los sabios e instruidos, se sentarán ante ellos (לפניהם).

Cuando esté preparada la mesa de la comunidad

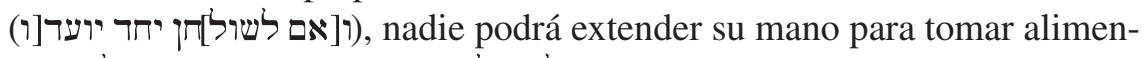
to (אל ישלח [איש את ידו ברשת הלחים) antes de la bendición del sacerdote (כיא[ הוא פיברך את רשית הלחם). Solo después el Mesías extenderá su

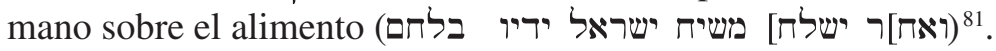

78 Se lo ha interpretado también como el «Mesías sacerdotal», diverso del «Mesías de Israel» que aparece más adelante, cf. D. SMITH, From Symposium to Eucharist, o. c., p. 156. Una discusión del tema excede los límites del trabajo, pero puede verse una síntesis de la problemática en J. A. Fitzmyer, The Dead Sea Scrolls and Christian Origins. Studies in the Dead Sea Scrolls and related Literature. Grand Rapids, 2000, pp. 84-86.

79 Cf. D. Sмiтн, From Symposium to Eucharist, o. c., pp. 156, 170-171.

80 El sentido del verbo יוליד es discutido, cf. J. J.ColuINS, «Interpretation of Psalm 2», en F. García Martínez (ed.), Echoes from the Caves. Qumran and the New Testament. Leiden-Boston, 2009, pp. 63-64.

81 Sobre el carácter escatológico de esta comida, cf. L. H. Schiffman, The Eschatological Community of the Dead Sea Scrolls. A Study of the Rule of the Congregation. Society of Biblical Literature Monograph Series. Atlanta, GA, 1989, p. 9. Esta inter- 
En este banquete solo tienen lugar los notables. Los agobiados por defectos físicos quedan excluidos del banquete común y no se sientan con el Mesías. Horsely ha afirmado que el paralelo de Qumrán más llamativo con el movimiento de Jesús en relación con el inminente advenimiento escatológico son precisamente las prácticas similares de comida comunitaria ${ }^{82}$.

Si esta opinión puede ser sostenida en relación con el tercer evangelio en lo que respecta a la expectativa escatológica (cf. Lc 22,14-19), sin embargo es evidente la diferencia abismal en lo que respecta a los comensales: si en aquella solo los «hombres de nombre» pueden participar del banquete, en la comensalidad del Jesús de Lucas son precisamente los sin nombre los que se convierten en comensales de honor. El Jesús lucano ha puesto de manifiesto con su ministerio aquello que había proclamado en el

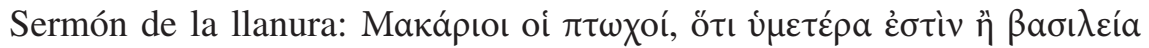

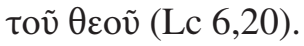

\subsubsection{Los comensales de los caminos y de las cercas}

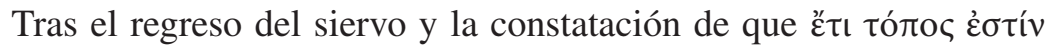

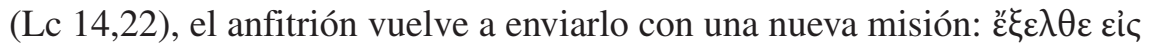

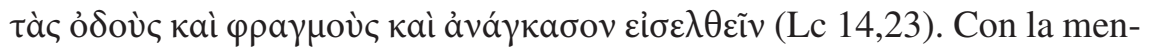
ción de las ỏoó́, el destino de este segundo envío lucano se acerca al único envío mateano (Mt 22,9-10) y al referido por la versión gnóstica de la parábola (EvTom 64,11).

El objetivo de este segundo envío no está centrado en los comensales, como en el evangelio apócrifo (EvTom 64,11). Se persigue otra intención:

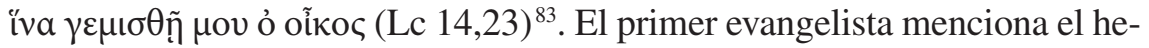

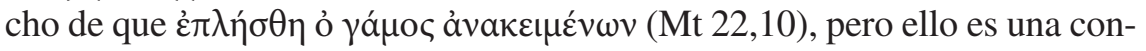

pretación no es unánime, y es posible comprenderla como la comida regular practicada por la comunidad, aunque sin excluir que «these meals may have prefigured a future messianic banquet». Cf. S. PFAnN, «A Table Prepared in the Wilderness: Pantries and Tables, Pure Food and Sacred Space at Qumran», en K. GALOR / J.-B. HumBert / J. Zangenberg (eds.), The Site of the Dead Sea Scrolls: Archaeological Interpretations and Debates. Proceedings of the Conference held at Brown University, November 17-19, 2002, en Studies on the Texts of the Desert of Judah 57 (2005), p. 168, n. 37.

82 Cf. R. HorsLey, «The Dead Sea Scrolls and the Historical Jesus», en J. H. ChaRLESWORTH (ed.), The Bible and the Dead Sea Scrolls. The Second Princeton Symposium on Judaism and Christian Origins III. Waco, TX, 2006, p. 43.

${ }_{83}$ El verbo $\gamma \varepsilon \mu i ́(\omega$ es poco usual en toda la Escritura griega: Gn 45,17; 3 Mac 5,47; Mc 4,37; 15,36; Lc 14,23; Jn 2,7; 6,13; Ap 8,5; 15,8. 
secuencia de la invitación de buenos y malos. Se trata de una situación provisoria que requiere una criba ulterior, expresada en la necesidad de tener el vestido de fiesta (Mt 22,11-13). En la pluma redaccional del tercer evangelista, la casa llena aparece más bien como una meta por realizar ${ }^{84}$.

La indeterminación de los últimos destinatarios de la invitación se presta a diversas interpretaciones. Hahn sugiere que son también personas marginales, al igual que las del primer envío ${ }^{85}$. Considera que en el uso de los verbos del primer y del segundo envío hay un incremento evidente ${ }^{86}$. A nuestro juicio, en la dinámica de la parábola lucana, una referencia repetida a los pobres y excluidos no implicaría un progreso en la trama del relato y podría ser incluso innecesaria, y este incremento o aumento se explica mejor si en el segundo envío del siervo se describe más bien la universalidad de los comensales: se abren las fronteras de Israel.

Smit sostiene, por el contrario, que tanto el segundo como el tercer envío del siervo han de interpretarse como referidos a los gentiles ${ }^{87}$. Sin embargo, la repetición de la misma lista de Lc 14,13, donde los mencionados no podrían comprenderse como gentiles, nos hace preferir la interpretación que ve una diferencia entre ambos grupos: a los excluidos dentro de Israel se suman los excluidos externos del pueblo elegido.

Ellos se presentan como los comensales inéditos de un banquete hasta ahora concebido de manera excluyente. Ello está en continuidad con el ministerio del Jesús lucano, que ha sido ungido precisamente para servir a los excluidos (Lc 4,16-21) y con la aseveración que él mismo realiza acerca de los nuevos comensales al banquete $(\operatorname{Lc} 13,29)^{88}$. La parábola se

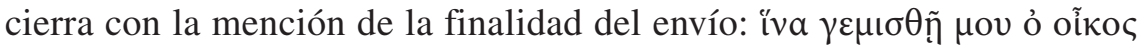
(Lc 14,23). Aquí reside, a juicio de varios exegetas, el peso de la parábo$1 \mathrm{l}^{89}$. No hay una descripción de la ejecución de la orden, y así el relato permanece abierto: en la casa del señor hay todavía lugares que cubrir ${ }^{90}$.

${ }^{84}$ Si bien afirma que ambos evangelistas tratan de manera diversa según sus intenciones el motivo de la fiesta o de la casa llena, a nuestro juicio son insuficientes las apreciaciones de T. SöDING, «Das Gleichnis von Festmahl», a. c., 63. La fiesta llena para Mateo es aún provisoria y fruto de la imperfección de la selección, para Lucas es la meta del envío del siervo.

${ }^{85}$ Cf. F. HAHN, «Das Gleichnis von der Einladung zum Festmahl», a. c., p. 349, n. 44.

${ }^{86}$ Cf. ibid., p. 345.

87 Cf. P.-B. Sміт, Fellowship and Food in the Kingdom, o. c., p. 165.

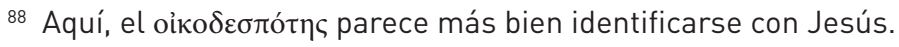

${ }^{89}$ Cf. P.-B. SмIт, Fellowship and Food in the Kingdom, o. c., p. 165; T. SöDING, «Das Gleichnis von Festmahl», a. c., pp. 74-75.

90 Cf. W. ECKEY, Das Lukasevangelium, o. c., p. 663. 


\subsubsection{El logion final}

Cada versión se cierra con un dicho sobre los invitados que han rechazado la invitación. La sentencia copta está puesta en labios de Jesús (EvTom 64,12). Refleja la intención redaccional de su autor, que ha insistido en excusas de carácter económico y comercial ${ }^{91}$ y expresa que las personas mundanas no escuchan la llamada a la gnosis ${ }^{92}$. La mano gnóstica se percibe especialmente en la expresión «los lugares de mi Padre», que designa los lugares celestiales adonde van las almas tras escapar de la esfera terrena ${ }^{93}$.

Mateo culmina con una sentencia acerca de los pocos que son escogidos (Mt 22,14), considerada como un comentario del narrador de la parábola, es decir, de Jesús ${ }^{94}$.

Lucas concluye la parábola con un juicio acerca de los invitados iniciales (Lc 14,24). A diferencia de Mateo, que cierra con un principio general, el tercer evangelista expresa más bien una exclusión de los personajes de la parábola. La interpretación de Hotze, según la cual la sentencia de Jesús ha de entenderse como «ninguno de ustedes, fariseos y jefes de Israel, participará en la comida escatológica en el reino de Dios» ${ }^{95}$, es extrema y exagerada ${ }^{96}$.

Un primer problema lo constituye la identificación del hablante. La solución más lógica sería atribuir estas palabras al señor de la parábola.

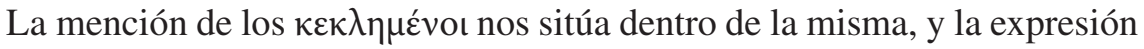

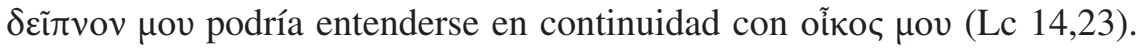
Dos dificultades se presentan para una tal atribución. En primer lugar, el

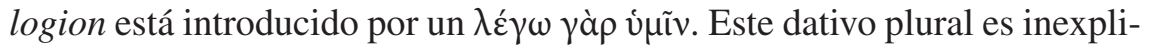
cable a nivel intradiegético: durante todo el relato no ha habido más que un interlocutor singular.

Por otra parte, la conclusión del capítulo sería defectuosa si la última palabra de la escena fuese intradiegética. Todo el marco narrativo elaborado por el evangelista requiere más bien un desenlace que vuelva a situar a Jesús entre los comensales. El $\lambda \dot{\varepsilon} \gamma \omega$ үà $\rho$ viñv se explica mejor si se los

91 Cf. ibid., p. 659.

92 Cf. U. Luz, El Evangelio según san Mateo, o. c., p. 311.

93 Cf. F. HAHN, «Das Gleichnis von der Einladung zum Festmahl», p. 348.

94 Cf. U. Luz, El Evangelio según san Mateo, p. 306.

95 G. Hotze, Jesus als Gast, pp. 254-255.

96 No obstante parece matizar sus propias afirmaciones, cf. G. HotzE, Jesus als Gast, pp. 255-256. 
supone como destinatarios. Es una manera de concluir sus parábolas $(\mathrm{Lc} 11,8 ; 15,7.10 ; 16,9 ; 18,8.14 ; 19,26)^{97}$.

Si esta interpretación es correcta, nos encontramos con consecuencias a nivel cristológico: saliendo de la parábola, el Jesús lucano habla por primera vez de «su» banquete en relación con el del reino. Ello establece un vínculo entre lo narrado en la parábola y su persona, a la vez que muestra una «enorme conciencia cristológica» ${ }^{98}$.

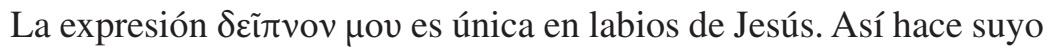
el banquete del señor, símbolo de Dios. Esta misma interrelación aparece

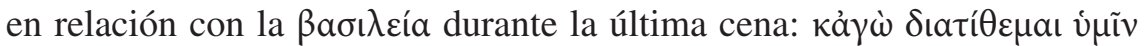

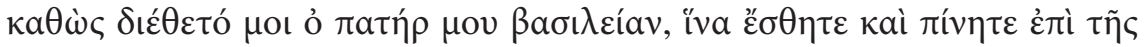

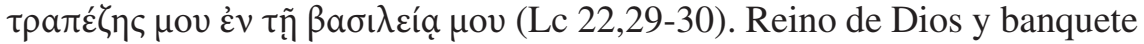
se entrelazan tanto en la visita del Jesús comensal a la casa del jefe fariseo (Lc 14,1-24) como en la última cena del Jesús anfitrión con sus discípulos. En ambos encontramos una coloración cristológica: el $\delta \varepsilon i \pi v v \nu \mu$ ov al igual

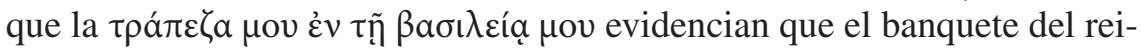
no no se entiende sin la referencia cristológica.

\section{Balance sintético de Lc 14,1-24}

A la luz de nuestro recorrido ofrecemos un puñado de consideraciones sintéticas. Comenzamos evidenciando la coherencia y la progresión lógica de la perícopa y ofrecemos algunas observaciones a propósito de la cristología.

La perícopa ha alcanzado una gran homogeneidad a partir de sus diversos materiales ${ }^{99}$. Lucas no solo ha sido hábil en darles coherencia, sino que también ha sabido engarzarlos de una manera progresiva dentro de un episodio que, partiendo de la comensalidad habitual de Jesús, arriba al anuncio del banquete escatológico. El evangelista ha tejido los diálogos con sentencias que paulatinamente han puesto de relieve su realidad (Lc $14,11 ; 14 ; 15 ; 24)$. Estas aseveraciones desempeñan una función medular en la coloración escatológica del pasaje.

Con el hapax diegumenon de la curación del hidrópico (Lc 14,2-6), Lucas pone de manifiesto no solo la precedencia del hombre sobre el sábado,

97 Cf. W. EckeY, Das Lukasevangelium, p. 663.

98 Cf. G. Hotze, Jesus als Gast, p. 254.

99 Cf. W. Braun, Feasting and Social Rhetoric in Luke 14, o. c., 14-21; G. HotzE, Jesus als Gast, o. c., pp. 256-257. 
sino además la urgencia de una salvación que no admite dilación (cf. Lc 13,3133). La sanación está en continuidad con su ministerio de curación (Lc 4,40; $9,11)$ y con su señorío sobre el día de descanso (Lc 6,6-11; 13,10-17). Su novedad radica en que por primera vez una curación tiene lugar en el marco de un banquete de sábado. Si bien no hay una transición clara con la escena siguiente y la curación comienza y acaba sin dejar «rastros» ulteriores en el desarrollo de la perícopa, ya ha aportado algo fundamental: la connotación soteriológica de la presencia del Jesús lucano en un banquete.

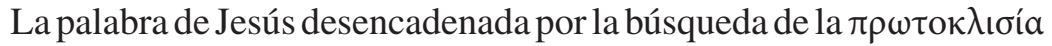
(Lc 14,8-11) es mucho más que una regla de mesa o una enseñanza sobre la humildad. El Jesús lucano es mucho más que un maestro de moral. Es la sentencia sobre la humillación y la exaltación la que insinúa la dimensión escatológica y orienta las palabras dirigidas a los comensales en una dirección contraria a la que proponía Dibelius cuando sostenía que de una advertencia escatológica se había llegado a una simple regla de mesa ${ }^{100}$. Lucas cuidará que esta insinuación de la dimensión escatológica aflore de manera inequívoca en la escena siguiente.

En ella, Jesús se dirige a su anfitrión exhortándolo a hacer partícipes del propio banquete a aquellos excluidos que no tienen posibilidad de retribuir la invitación (Lc 14,12-13). Si en su banquete anterior con los fariseos los había exhortado a la limosna (Lc 11,41), aquí nos encontramos con una exhortación más radical: se trata de una participación en la intimidad de la propia fiesta y de la propia alegría. Nuevamente, una sentencia final evidencia el alcance trascendente de la palabra pronunciada. El Jesús lucano no solo se ha sentado a la mesa farisea pronunciando contra ellos duros ov̉aí, (Lc 11,37-53), sino que también visita a uno de sus jefes y lo procla-

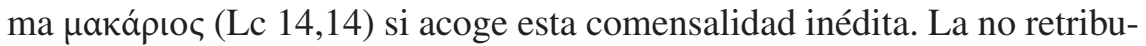
ción de los outcasts se verá subsanada por una retribución mayor y con un banquete superior en la resurrección de los justos.

Un comensal anónimo interviene con otro macarismo (Lc 14,15). Es la primera escena de comida del evangelio en la que el ministerio comensal de Jesús se funde explícitamente con la comensalidad del reino escatológi-

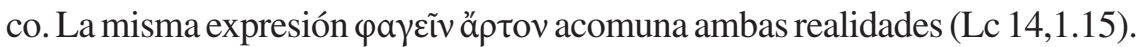
Con esta última intervención nos encontramos con el clímax del «ascenso» escatológico del pasaje.

La respuesta de Jesús pone en evidencia el drama del rechazo y de la autoexclusión del banquete escatológico (Lc 14,16-20). Con la parábola

100 Cf. M. Dibelius, Die Formgeschichte des Evangeliums. Tübingen, ${ }^{2} 1933$, pp. $248-$ 249. 
final, el comensal lucano se hace exegeta del banquete del reino, de su lógica y de sus exigencias radicales. Los nuevos invitados (Lc 14,21) son los mismos outcasts que han sido los destinatarios privilegiados del ministerio de Jesús (Lc 4,16-21). El comensal galileo es así también el siervo que ofrece la salvación a aquellos que se encuentran en la periferia de la historia.

La sentencia final del Jesús lucano (Lc 14,24) no es una declaración de exclusión definitiva, sino una parénesis contundente que pone de relieve la urgencia de la opción por el reino.

Esta progresividad dentro de Lc 14,1-24 es, en cierto sentido, análoga a la que podemos percibir en el itinerario narrativo lucano: durante todo el ministerio galileo, el Jesús lucano visita especialmente a los pecadores y come con ellos (Lc 5,29-32). En casa de un fariseo, el perdón divino se hace presente en el corazón destrozado de una mujer pecadora ( $\mathrm{Lc} 7,36-$ 50). La última meal scene del ministerio galileo ofrecerá una novedad: por primera vez aparece como anfitrión de las multitudes que han venido a escucharlo hablar del reino y a hacerse curar de sus enfermedades (Lc 9,1017). Esta primera sección nos sugiere así un paso de la imagen del comensal que busca a los perdidos con la del anfitrión que recibe a las multitudes que lo siguen.

La comensalidad durante el ministerio en Galilea está empapado de la soteriología, pero la cristalización de su alcance escatológico es peculiaridad de la sección central (Lc 12,35-38; 13,22-30; 14,1-24). Es precisamente durante su subida hacia Jerusalén donde se hace palpable la tensión escatológica. Crece a medida que Jesús sube hacia Jerusalén. Si bien el evangelista pretende corregir la expectativa de una parusía inminente ${ }^{101}$, una cierta relación entre su subida hasta la capital santa y la tensión escatológica no puede excluirse de la intención lucana. De hecho, la sección del Reisebericht contiene varias perícopas empapadas de una u otra manera de la tensión escatológica (Lc 10,14-15.25; 11,31; 12,8-9.35-47; 13,22-30; 16,9.19-31; 17,20-21.22-37; 18,19; 19,11-27). Una tal concentración de alusiones o referencias explícitas no tiene paralelo en la sección del ministerio galileo.

En este contexto, nuestro pasaje no solo es una perícopa más en la serie de textos escatológicos del Reisebericht, sino que además colorea esta escatología con tonos convivales. Así se encuentran por primera vez de manera explícita la comensalidad de Jesús y la teología del banquete escatológico del reino. Las insinuaciones previas (Lc 12,35-38; 13,22-30) toman

101 Cf. F. Bovon, L'Évangile selon Saint Luc $(15,1-19,27)$. Commentaire du Nouveau Testament IIlc. Genève, 2001, pp. 256-257. 
ahora la forma de un relato en el cual el comensal aprovecha el banquete al que ha sido invitado para exhortar a hacerse comensal del banquete del reino. Ello nos permite intuir con fundamento una relación en la mente teológico-redaccional de Lucas entre estos dos motivos; entre los banquetes del ministerio de Jesús y el banquete escatológico. Se ha afirmado justamente que «la entrada de Jesús a una casa [...] tiene que ver siempre con la salvación del que es allí visitado» ${ }^{102}$. Podríamos incluso precisar más: la entrada de Jesús a una casa y el sentarse a la mesa tienen siempre que ver en alguna medida con la mesa del banquete del reino.

En esta escatología convival, la cristología desempeña un rol esencial: el banquete del reino no se entiende sin la mediación de Jesús. Desde el capítulo 14 se puede leer en cierto sentido todo su ministerio e interpretarlo como un ministerio al servicio del banquete del reino. Parafraseando al mismo Lucas podríamos decir que Jesús «pasó invitando al banquete del reino» (cf. Hch 10,38). Ello aparece posiblemente evocado con la figura del siervo de la parábola (Lc 14,17.21-23).

Esta mediación cristológica alcanza su cenit cuando, además de sier-

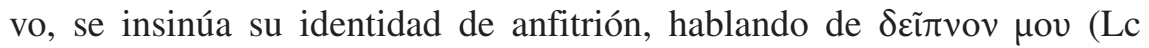
14,24). Será la identidad que asumirá de manera clara en Jerusalén durante la última cena (Lc 22,14-20), aludiendo a un banquete del que es coanfitrión con el Padre (Lc 22,28-30) y la identidad que mantendrá después de su resurrección (Lc 24,28-32).

En Lc 14,1-24 nos encontramos con un relato gozne entre el Jesús comensal y el Jesús servidor y anfitrión del reino. La cristología lucana no se entiende sin esta interrelación de imágenes. Su interacción en la trama pone de relieve la riqueza y complejidad de una cristología en gran parte modelada por la teología del banquete escatológico ${ }^{103}$. La escatología convival del tercer evangelista impregna toda su cristología.

\section{Consideraciones finales}

El dramaturgo francés Molière pone en boca de su personaje Socia una frase que ha hecho fortuna: «El verdadero Anfitrión es el Anfitrión

102 G. HotZE, Jesus als Gast, o. c., p. 258.

103 No nos parece suficiente la interpretación un tanto «nestoriana» de G. Hotze: «Gast und Gastgeber repräsentieren die beiden Existenzweisen Jesu Christi: Der Gast steht für den Menschen Jesus, der Gastgeber für Christus, den Soter und Kyrios», en Jesus als Gast, o. c., p. 300. 
donde se cena» ${ }^{104}$. Inspirada en el Anfitrión de Plauto (254-184 a. C.), la obra cuenta las vicisitudes del rey Anfitrión y el dios Zeus. Este último se había hecho pasar por el rey para poder seducir a su esposa Alcmena. La frase de Socia manifiesta cómo el verdadero Anfitrión es reconocido finalmente por el esplendor de sus banquetes. De este nombre propio del personaje nace nuestra palabra «anfitrión», usada para designar a aquel que tiene invitados a su mesa o a su casa.

A diferencia de la simulación de Zeus, el Dios veterotestamentario se revela como verdadero anfitrión de la humanidad, porque invita a su pueblo a participar de una salvación cuya plenitud no puede expresarse mejor que con la imagen del banquete escatológico. Allí, la alegría, la abundancia y la fiesta borrarán toda huella de lágrimas y de heridas (cf. Is 25,6-8). Será el hogar definitivo del hombre: «El banquete es la imagen de la basileia consumada: una comunión fundada por Dios en la que los extranjeros encuentran un hogar definitivo y donde todos los dones de Dios se dan en abundancia» ${ }^{105}$.

En la trama lucana, este verdadero anfitrión visita a su pueblo en la persona y ministerio de Jesús de Nazaret (Lc 1,68.78), como ya en los albores de la historia de salvación había visitado a Abrahán y se había sentado con él (cf. Gn 18,1-15). Lo hace para recordarle al hombre que tiene vocación de banquete y para invitarlo a su mesa escatológica.

Pasará como el comensal que elige el último lugar y como el anfitrión que invita a los últimos. Así hace presente el misterio de un reino en el cual su Padre ha elegido como invitados de honor a los pobres, a los pequeños, a los ciegos y a los cojos, a los sin nombre. En su banquete no cabe la exclusividad para los אנושי השם. El Padre del comensal galileo no quiere comenzar su fiesta sin el débil, el frágil o aquel que, oprimido por el peso de su miseria, no se atreve a levantar sus ojos al cielo (cf. Lc 18,13). Los pecadores que han acogido a Jesús descubren en él la hospitalidad de un Dios anfitrión que los abraza con misericordia y hace un banquete de fiesta por su regreso (cf. Lc 15,24).

Pero, paradójicamente, aun en el eschaton el anfitrión seguirá siendo siervo: en uno de los pasajes más sorprendentes de todo su evangelio, Lucas presenta al señor que invita a sus siervos a su mesa, pero es él mismo quien se pone a servirlos (cf. Lc 12,37). Incluso en el banquete futuro del reino, el anfitrión continuará estando a la mesa como quien sirve

104 Molı̇ère, Amphitryon, acto III, escena V: «Le véritable Amphitryon est l'Amphitryon où l'on dîne».

105 T. SöDING, «Das Gleichnis von Festmahl», a. c., p. 83. 
(Lc 22,27). Con ello, el Jesús lucano testimonia a un Dios que tiene al hombre en el centro de su atención salvífica. Valga el oxímoron: nos revela a un Dios antropocéntrico que no solo lo invita a su banquete y lo exalta a la dignidad de ser huésped de su mesa, sino que además se pone humildemente al servicio de su plenitud escatológica.

AdRián J. TARANZANO

Múnich, Alemania 